\title{
The Future of Roots, Tubers and Bananas
}

\author{
Arega Alene ${ }^{1}$, Marcel Gatto², Sika Gbegbelegbe², Guy Hareau², Julius Okello³
}

December 16, 2021

1. International Institute of Tropical Agriculture (IITA) - Malawi

2. International Potato Center (CIP) - Peru

3. International Potato Center (CIP) - Uganda

This document is part of a series of short papers on "The Future of X", produced as part of foresight-related research supported by the CGIAR Research Program on Policies, Institutions, and Markets, and edited by Keith Wiebe (IFPRI) and Steven Prager (Alliance of Bioversity and (IAT). These short papers are intended to provide a focused, forward-looking perspective on key issues to support discussion on food, land, and water systems transformation. We thank two anonymous reviewers for their comments on an earlier draft.

This is an accepted version presented as a pre-print. It is currently undergoing final revision, editing, and production. A final version will be made available at http://foresight.cgiar.org.

\section{What's the issue?}

The global demand for roots, tubers, and bananas (RTB) is projected to reach 1.4 billion tons in 2050, which represents a 50\% increase over 2010 under a baseline scenario involving moderate growth in per capita income and high greenhouse gas emissions worldwide [1]. Consistent with the region's population and income growth projections, sub-Saharan Africa (SSA) is projected to become the largest consumer and producer of RTB crops [2]. In terms of utilization, RTB crops are primarily used for food consumption across the developing world, and this is projected to remain so in the future [2]. Major drivers such as income growth and urbanization affect consumer preferences, whereas population growth increases demand. Climate change, on the other hand, is projected to negatively affect global food production by increasing long-term temperature and altering long-term rainfall patterns, with greatest impacts expected in SSA. While potato and banana are sensitive to water stress, drought-tolerant crops like cassava, yam and sweet potato fare better under climate-induced stressors than major cereals. Banana is expected to have the highest growth in supply and demand among all RTB crops and across all regions (Fig. 1), with the increased production being driven by land expansion [2]. Given future land pressures due to population growth, rapid urbanization, and competition with other crops, the increasing supply of banana will require cropping system intensification and adoption of such management practices as intercropping with coffee [3]. 

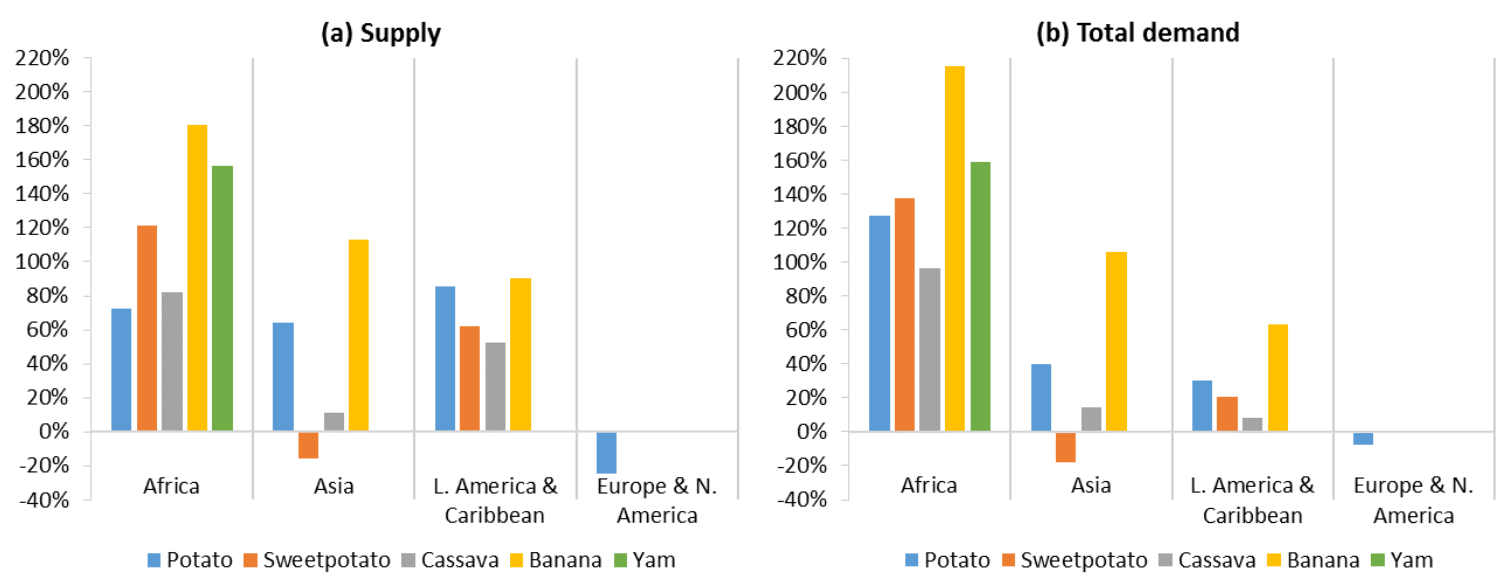

Figure 1: Changes in RTB production and demand for 2010-2050

Note: Reprinted from Understanding the consequences of changes in the production frontiers for roots, tubers and bananas, by Petsakos et al. 2019, p.183, copyright by 'Global Food Security'

The per capita consumption of RTB crops and their energy contribution to human diets is projected to increase in developing countries, particularly in Africa [1,2], but the relative change is smaller compared to other commodities. Elsewhere, the percentage calorie intake from RTB crops will decrease slightly, following the expected shift from traditional staples towards other foods, primarily meat. Despite these regional dietary differences, the RTB energy contribution to diets is expected to increase by 2050 globally. For cassava and yam, the potential for productivity growth by 2050 could be an important driver for increasing RTB consumption in SSA [4]. Rosegrant et al. (2017) project a significant supply increase for yam and cassava in Africa that will be achieved through yield improvements [1]. Sweet potato production is also expected to more than double in Africa, driven mainly by agricultural technology adoption and productivity growth in response to a growing market demand for nutritious staples to combat vitamin A deficiency. Potato's high-income elasticity of demand may prove an important driver for production increase in some developing countries [4]. In Africa, economic growth by 2050 is thus likely to result in higher consumption levels for potato, which may lead to further productivity growth and investment from the processing industry [5]. Rosegrant et al. (2017) report similar findings for Latin America and the Caribbean (LAC) and Asia, most notable in Indian [1] There, land expansion is projected to increase potato supply by $180 \%$ compared to 2010, surpassing the expected increases in food demand due to population growth alone. Potato is also more affected by changing preferences than are other RTB crops, especially in countries like China where the baseline scenario posits rapid economic development but low population growth.

\section{What research has been done? What has the research found?}

Increasing agricultural production to the levels needed to feed an expanding population requires increased public investments in research and development (R\&D) to enable the development and adoption of new technologies. Rosegrant et al. (2017) show that increased 
R\&D investments across the developing world have the potential for achieving significant RTB productivity gains and inducing demand growth due to lower prices [1]. Yield-increasing investments are expected to increase food availability and the energy contribution of RTB crops to human diets in the developing world compared to the baseline scenario for 2050 [1]. Petsakos et al. (2019) show that strategic investments in research for development (R4D) to increase agricultural productivity would lead to substantial increases in production and consumption of RTBs in LAC, SSA and Asia [2]. In addition, more spatially targeted investments can further strengthen the role of RTB crops as food security crops. Specifically, investments aimed at increasing productivity in regions which are expected to face high population pressures, such as Sub-Saharan Africa and South Asia, can serve to effectively increase supply and reduce import dependence, thus enhancing food security [1, 2].

Maximizing the impacts of research investments requires sharpening the focus of research on those options with the greatest impacts. Given the current and future challenges to the productivity of RTB crops, expert consultations were recently conducted to identify plausible technologies to tackle such challenges. The priority assessment effort, supported by the CGIAR Research Program on Roots, Tubers, and Bananas (CRP-RTB), identified the research and technology options with the greatest expected impact on production and returns on investments in RTB across the developing world. Priorities included improved seed systems, agronomic practices and varieties resistant to pests and diseases [6-10]. For cassava, for example, improving the quality and supply of planting material and promoting integrated crop and soil fertility management options have the largest potential economic and poverty reduction impacts [6]. Efficient planting material production and distribution systems can go a long way in addressing the observed low adoption of improved varieties due to lack of clean planting materials. Sustainable crop and soil fertility management practices also play a key role in closing the observed yield gaps for cassava, especially in Africa. Similarly, the high-priority research options for other RTB crops include clean planting materials and agronomic practices for yam [11, 12]; management of bacterial wilt and bunchy top virus disease for banana [10]; late blight- and virus disease-resistant varieties for potatoes [8]; and orange-fleshed and virus disease-resistant varieties for sweet potato [9]. Results are summarized below in Table 1. 


\begin{tabular}{|c|c|c|c|c|}
\hline Cassava & Yam & Potato & Sweet potato & Banana \\
\hline $\begin{array}{l}\text { Sustainable crop and } \\
\text { soil fertility } \\
\text { management } \\
\text { practices (rank: } 1 \text { ) }\end{array}$ & $\begin{array}{l}\text { Improved yam varieties } \\
\text { with complementary } \\
\text { integrated crop } \\
\text { management (ICM) } \\
\text { options (rank: } 1 \text { ) }\end{array}$ & $\begin{array}{l}\text { Development of LB } \\
\text { resistant potato } \\
\text { varieties (rank: } 1 \text { ) }\end{array}$ & $\begin{array}{l}\text { Breeding for sweet } \\
\text { potato virus disease } \\
\text { (SPVD)-resistant } \\
\text { varieties (rank: } 1 \text { ) }\end{array}$ & $\begin{array}{l}\text { BXW management: } \\
\text { cultural practices (rank: } \\
\text { 1) }\end{array}$ \\
\hline $\begin{array}{c}\text { Efficient and } \\
\text { massive high-quality } \\
\text { planting material } \\
\text { production and } \\
\text { distribution } \\
\text { systems (rank: } 2 \text { ) } \\
\end{array}$ & $\begin{array}{c}\text { Clean planting } \\
\text { materials and } \\
\text { agronomic practices } \\
\text { (rank: } 2 \text { ) }\end{array}$ & $\begin{array}{l}\text { Development of virus } \\
\text { resistant potato } \\
\text { varieties (PVY, PLRV, } \\
\text { PVS, PVX) (rank: 2) }\end{array}$ & $\begin{array}{l}\text { Breeding for OFSP } \\
\text { with high content of } \\
\text { provitamin A and } \\
\text { other micro-nutrients } \\
\text { (rank: } 2 \text { ) }\end{array}$ & $\begin{array}{l}\text { Recovery from BBTV } \\
\text { (rank: } 2 \text { ) }\end{array}$ \\
\hline $\begin{array}{l}\text { Integrated pest and } \\
\text { disease } \\
\text { management } \\
\text { practices, including } \\
\text { resistant varieties } \\
\text { (rank: } 3 \text { ) }\end{array}$ & $\begin{array}{c}\text { Pest and disease } \\
\text { management options } \\
\text { (rank: } 3 \text { ) }\end{array}$ & $\begin{array}{l}\text { Intensification of } \\
\text { cereal based } \\
\text { systems: introducing } \\
\text { the agile potato (70- } \\
100 \text { days) (rank: } 3 \text { ) }\end{array}$ & $\begin{array}{c}\text { Development of } \\
\text { weevil resistant sweet } \\
\text { potato varieties (rank: } \\
\text { 3) }\end{array}$ & $\begin{array}{l}\text { Resistant (pests and } \\
\text { diseases) plantain ready } \\
\text { for release in } 2014 \\
\text { (rank: 3) }\end{array}$ \\
\hline $\begin{array}{c}\text { Processing } \\
\text { technologies for } \\
\text { value addition (rank: } \\
\text { 4) }\end{array}$ & $\begin{array}{l}\text { ICM interventions } \\
\text { (rank: 4) }\end{array}$ & $\begin{array}{l}\text { Development of } \\
\text { potato varieties } \\
\text { resistant to BW } \\
\text { (rank: 4) }\end{array}$ & $\begin{array}{l}\text { Quality planting } \\
\text { materials and } \\
\text { improved seed } \\
\text { systems, including } \\
\text { SPVD management } \\
\text { (rank: 4) }\end{array}$ & $\begin{array}{c}\text { Cropping system } \\
\text { intensification (rank: 4) }\end{array}$ \\
\hline $\begin{array}{c}\text { High-yielding, } \\
\text { drought-tolerant } \\
\text { varieties and } \\
\text { increased water-use } \\
\text { efficiency (rank:5) }\end{array}$ & $\begin{array}{l}\text { Production of new } \\
\text { processed yam } \\
\text { products and } \\
\text { processing equipment } \\
\text { (rank: } 5 \text { ) }\end{array}$ & $\begin{array}{c}\text { Development of } \\
\text { potato value chains } \\
\text { (rank: 5) }\end{array}$ & $\begin{array}{l}\text { Breeding for high dry } \\
\text { matter* }\end{array}$ & $\begin{array}{c}\text { Resistant } \\
\text { (pests/diseases) } \\
\text { plantain to be } \\
\text { developed through } \\
\text { breeding (rank: 5) }\end{array}$ \\
\hline $\begin{array}{l}\text { High-yielding } \\
\text { varieties with high } \\
\text { dry matter and } \\
\text { starch (rank: 6) }\end{array}$ & & $\begin{array}{c}\text { Seed systems: } \\
\text { improving seed } \\
\text { production and } \\
\text { distribution (rank: 6) }\end{array}$ & $\begin{array}{c}\text { Early harvest (2.5-3 } \\
\text { months after } \\
\text { planting) }{ }^{*}\end{array}$ & $\begin{array}{c}\text { Resistant } \\
\text { (pests/diseases) East } \\
\text { African Highland } \\
\text { Banana ready for } \\
\text { release in } 2014 \text { (rank: 6) }\end{array}$ \\
\hline $\begin{array}{l}\text { Strategies to } \\
\text { prevent introduction } \\
\text { of exotic pests and } \\
\text { diseases (rank: } 7 \text { ) }\end{array}$ & & $\begin{array}{c}\text { Improved water use } \\
\text { efficiency, including } \\
\text { drought tolerant } \\
\text { varieties* }\end{array}$ & $\begin{array}{l}\text { Breeding for high } \\
\text { yield only* }\end{array}$ & $\begin{array}{l}\text { BXW management: } \\
\text { GM-resistant varieties } \\
\text { (rank: 7) }\end{array}$ \\
\hline $\begin{array}{l}\text { High-yielding } \\
\text { varieties with } \\
\text { resistance to major } \\
\text { diseases (rank: 8) }\end{array}$ & & $\begin{array}{l}\text { Breeding for high } \\
\text { yield* }\end{array}$ & $\begin{array}{l}\text { Breeding for drought } \\
\text { tolerance and other } \\
\text { abiotic stresses* }\end{array}$ & $\begin{array}{c}\text { Resistant } \\
\text { (pests/diseases) East } \\
\text { African Highland } \\
\text { Banana to be } \\
\text { developed through } \\
\text { breeding (rank: } 8 \text { ) }\end{array}$ \\
\hline \multicolumn{5}{|l|}{$\begin{array}{c}\text { High-yielding } \\
\text { varieties with longer } \\
\text { shelf life (rank: 9) } \\
\end{array}$} \\
\hline $\begin{array}{l}\text { High-yielding } \\
\text { varieties tolerant to } \\
\text { cold weather and } \\
\text { frost (rank: } 10 \text { ) }\end{array}$ & & & & \\
\hline
\end{tabular}

Table 1: Research and technology options identified through expert consultation process and ranked based on their projected economic benefits 


\section{What gaps deserve further work?}

In many developing countries, the full yielding capacity of RTB crops is limited by poor soil and water management practices, lack of quality planting material, and pests and diseases [6]. Adoption of improved/recommended agronomic practices is key to closing the yield gaps, especially when combined with favorable market conditions. RTB crops are drought-tolerant crops and hence have an edge over other crops such as maize and wheat. However, climate change will affect future crop yields through abiotic stresses and will also have an indirect effect through changes in the ecological niches of related pests and diseases. As shown in Table 1, RTB research and technology options with high potential impacts include varieties with resistance to pests and/or diseases for each RTB crop. Future research is thus required to quantify the impacts of climate change on biotic stresses and to identify possible intervention options to mitigate the negative impacts of climate change on the production of RTB crops. Furthermore, knowledge gaps remain concerning the competition between food, feed and fuel use of RTB crops. Although the modeling framework employed by Rosegrant et al. (2017) addresses the food vs feed question endogenously, it does not examine how the increasing demand for biofuels can affect the food security role of RTB crops [1]. Production of ethanol from cassava and sweet potato is a practice that is being pursued in several countries such as China and Indonesia ${ }^{12}$ and may put additional pressure on RTB production systems. It is recognized that increased public investments are needed to meet the growing food security needs of an expanding population through increased production of RTB crops, but further research is needed to estimate the levels of the current as well as additional public and private sector R\&D investments required to meet future food demand.

\section{References}

1. Rosegrant, M. W. et al. Quantitative foresight modeling to inform the CGIAR research portfolio. (International Food Policy Research Institute, 2017).

2. Petsakos, A. et al. Understanding the consequences of changes in the production frontiers for roots, tubers and bananas. Glob. Food Sec. 20, 180-188 (2019).

3. van Asten, P. J. A., Wairegi, L. W. I., Mukasa, D. \& Uringi, N. O. Agronomic and economic benefits of coffee-banana intercropping in Uganda's smallholder farming systems. Agric. Syst. 104, 326-334 (2011).

4. Alexandratos, N. \& Bruinsma, J. World agriculture towards 2030/2050: the 2012 revision. (2012).

5. Scott, G. J. \& Suarez, V. The rise of Asia as the centre of global potato production and some implications for industry. Potato J. (2012). 
6. Alene, A. D. et al. Identifying crop research priorities based on potential economic and poverty reduction impacts: The case of cassava in Africa, Asia, and Latin America. PLoS One 13, e0201803 (2018).

7. Abdoulaye, T., Alene, A., Rusike, J. \& Adebayo, A. Strategic Assessment of Yam Research Priorities - RTB Working Paper 2014-3. (2014).

8. Hareau, G. et al. Strategic assessment of research priorities for potato - RTB Working Paper 2014-8. (2014).

9. Hareau, G. et al. Strategic assessment of research priorities for sweetpotato. RTB Working Paper 2014-9. (2014).

10. Pemsl, D. E. \& Staver, C. Strategic Assessment of Banana Research Priorities. Lima (Peru). CGIAR Research Program on Roots, Tubers and Bananas (RTB) - RTB Working Paper 20142. (2014).

11. Mignouna, D. B. et al. Potential returns to yam research investment in sub-Saharan Africa and beyond. Outlook Agric. 0030727020918388 (2020).

12. Qiu, H. et al. Bioethanol development in China and the potential impacts on its agricultural economy. Appl. Energy 87, 76-83 (2010). 